\title{
The Strategic Significance of Increasing the Soft Power of Scientific and Technological Culture in Building a Culturally Advanced Country
}

\author{
Yingzi Xiong \\ Wuhan University of Technology, Wuhan, Hubei Province, China
}

Keywords: Soft Power of Scientific and Technological Culture; Culturally Advanced Country; Strategic Significance; Modernization.

\begin{abstract}
Scientific and technological culture occupies an important position in the process of human modernization; scientific and technological culture supports the soft power of science, technology and culture. Under the background of globalization and fierce competitions of science and technology, it is necessary for China to build the scientific and technological culture in the cause of constructing a socialist country with Chinese characteristics. This paper mainly expounds the essential strategic significance of increasing the soft power of scientific and technological culture from three aspects. First, strategic significance: soft power of scientific and technological culture can strategically support the building of a great culture in China. Second, directional significance: soft power of scientific and technological culture is the guide for constructing a culturally advanced country. Third, the overall significance: soft power of scientific and technological culture is the need of China's overall development under the background of new era.
\end{abstract}

\section{Introduction}

The Report of the 19th National Congress of the Communist Party of China pointed out: "Culture is a country and nation's soul. Our country will thrive only if our culture thrives, and our nation will be strong only if our culture is strong. Without full confidence in our culture, without a rich and prosperous culture, the Chinese nation will not be able to rejuvenate itself. We must develop a socialist culture with Chinese characteristics, inspire the cultural creativity of our whole nation, and develop a great socialist culture in China." Science and technology constitutes the primary productive force; the soft power of scientific and technological culture is an important element in the process of building a great socialist culture in China. Under the international background of the mutual-influence of cultural, economic and political factors, comprehensive national power of a country is more reflected in its cultural competitiveness. The development of scientific and technological culture can directly affect the development level of economy, science and technology, and measure a country's economic power as well as its scientific and technological strength. The goal of building a strong socialist country cannot be achieved without the development of scientific and technological culture. Advanced scientific and technological culture is the foundation of constructing a strong socialist country with Chinese characteristics.

Modern civilization comes with the development of modern science and technology. Contemporary scientific and technological culture, as the basis of scientific and technological development, is the inevitable choice for our country to build a great socialist culture. The construction of socialism with Chinese characteristics requires the development of scientific and technological culture. However, China's soft power of scientific and technological culture is relatively weak and lack of international competitive advantages. Strengthening the soft power of scientific and technological culture is of strategic significance to the construction of a great socialist culture in China. 


\section{Strategic Significance: the Soft Power of Scientific and Technological Culture can Strategically Support the Construction of a Culturally Advanced Country with Chinese Characteristics}

Building a great socialist culture requires science and technology; the development of science and technology cannot be separated from advanced scientific and technological culture. As a kind of soft power, scientific and technological culture will definitely increase China's cultural power.

The extensive and profound traditional culture of China has a complete system, as well as distinct features and clear historical contexts. It is rich in elements of cultural soft power. The philosophical wisdom, rational values and the humanistic spirit in our traditional value can adapt to the development of human society to a great extent. As a developing country, China inherits the historical and cultural quintessence of 5000 years. Based on national conditions, now China follows the road of socialism with Chinese characteristics. It is a road which integrates Chinese traditional culture into socialism construction with Chinese characteristics. As a large country with profound historical civilization, China enjoys profound cultural resources to a certain degree.

Productivity is the driving force of economic development; science and technology constitutes the primary productive force; advanced scientific and technological culture is the most important condition for the development of science and technology. Modern science and technology changes people's way of life; scientific and technological culture has profound influence on people's spiritual world. Science and technology is the key word of modern social development.

The soft power of scientific and technological culture combines not only with the essence of our traditional culture, but also with scientific and technological fruits which closely link to people's food, clothing, shelter and transportation. It relates to the characteristics of modern science and technology, and promotes the pace of developing a great socialist culture. The soft power of scientific and technological culture can point out the reasonable development direction for us, and promote the cultural development of our country to a higher level.

Therefore, we must vigorously increase the soft power of scientific and technological culture. Under the guidance of systematic philosophy, we need to build a scientific and cultural system from overall strategic perspective, and give full play to the strategic supporting functions of the soft power of scientific and technological culture in the process of building a great socialist culture with Chinese characteristics. It can help to promote the economic and social development of our country and promote the construction of a great socialist culture with Chinese characteristics.

\section{Directional Significance: the Soft Power of Scientific and Technological Culture can Guide the Direction of China's Construction towards a Culturally Advanced Country}

The construction of socialism with Chinese characteristics needs the development of scientific and technological culture. As a kind of soft power, scientific and technological culture is a spiritual force which can guide China to building a great culture in the right direction.

\subsection{The rise of a culturally advanced country needs the rise of soft power in scientific and technological culture.}

Culture is the name card and identification code of a nation in the process of globalization. It is the collective memory, the cultural symbol and the spiritual home of people. Culture is also an important embodiment of comprehensive national power. In modern society, the connotation of culture is becoming increasingly abundant. Common culture has become an important source of national cohesion and creativity; colorful spiritual and cultural life has become the aspiration of the Chinese nation. The importance of scientific and technological culture is becoming increasingly prominent. The soft power of scientific and technological culture has become an important support of economic and social development, and an important factor in China's comprehensive national power.

Nowadays China is constantly changing, developing and progressing. In the world, various ideological and cultural concepts are constantly blending and conflicting. The values hold by Chinese 
people also become changeable and diversified. Advanced scientific and technological culture should occupy the cultural market; old cultural forms should be gradually eliminated. China needs the rise and innovation of scientific and technological culture to lead the development of science and technology.

The rise of a great country is inseparable from the rise of cultural ideas. Scientific and technological culture is the most advanced modern culture. The soft power of scientific and technological culture can test the development level of national culture. China's economic rise since the reform and opening up is an indisputable fact; now we should realize the cultural renaissance and improve cultural competitiveness under the guidance of scientific and technological culture. The development of a big country includes economic and cultural development, science and technology development, as well as scientific and technological culture development. The development is not only about the continuous promotion of scientific and technological level, but also about the continuous enhancement of the soft power of scientific and technological culture. Nowadays, China should try to become a cultural power with the constantly increasing soft power of scientific and technological culture.

The soft power of scientific and technological culture urges us to be vigilant and sober, insist on traditional virtues of the Chinese nation, develop socialism with Chinese characteristics, and construct scientific norms and spirit which can adapt to the development of modern science, technology and culture. The scientific and technological culture system should be built according to Chinese characteristics and foreign experiences. Only in this way can we strengthen the soft power of scientific and technological culture, and build a great socialist culture in China.

\subsection{The construction of a culturally advanced country requires the promotion of soft power of scientific and technological culture.}

Building a culturally advanced country is conducive to the formation of strong national cohesive force. A country without cohesion cannot be powerful. Now the society is pluralistic in interests and thoughts; the Chinese ideology and culture has new characteristics like diversity, selectivity and variety. In such circumstances, how to enhance the cohesion of the Chinese nation is a problem we need to solve. In my opinion, to build a culturally advanced country, the first thing is to integrate the whole society through culture and form strong national cohesion.

Promoting the development of the soft power of scientific and technological culture and building a corresponding core value system can help our nation to find out the correct direction of social development and gather national forces to build a harmonious social environment. Scientific and technological culture includes scientific and technological knowledge and spirit; scientific spirit is the core of this value system. Under the influence of scientific and technological culture, we can create good cultural atmosphere, guide people to establish scientific outlook on life and the world, and maximize national cohesion. Only through the maximal and rational national cohesion can we constantly increase the soft power of scientific and technological culture and constantly promote the development of cultural power.

\section{The Overall Significance: the Soft Power of Scientific and Technological Culture is the Need of China's Overall Development under the Background of New Era.}

Cultural power is an important part of China's comprehensive national power. Competition in soft power of scientific and technological culture is the trend of world competition. We should conform to the trend and take the overall situation.

4.1 The soft power of scientific and technological culture is an important manifestation of comprehensive national power and the requirement of safeguarding national security, especially national cultural security.

The comprehensive national power refers to the total strength of a sovereign state and its international influence. It includes economic, political, scientific and technological, military, diplomatic, cultural and spiritual powers, as well as basic capacities of geographical environment, 
natural resources and population. In the fierce international competition, only countries with strong comprehensive national powers can occupy the dominant position. Improving comprehensive national power requires the improvement of citizens' scientific qualities and cutting-edge scientific and technological achievements.

Over the past three decades of reform and opening up, China's "hard power" of economy, science and technology has developed rapidly; the comprehensive national power has been further improved. At present, China has become the second largest economy in the world with the biggest foreign exchange reserve. However, compared with economic, scientific and technological strength, the soft power of scientific and technological culture of China is still weak. In the new stage, there are many difficulties to overcome and many social contradictions to resolve. Mental drive and intellectual support are extremely important in this period. To build a culturally advanced country, the socialist culture should play its role in the cause of modernization through promoting economic, political and social development. The restructuring of economic and social structures and the renewal of economic development concepts are inseparable from the intellectual and spiritual supports provided by the soft power of scientific and technological culture. Deepening the reform of cultural system, rationally constructing the system of scientific and technological culture, and further improving the soft power of scientific and technological culture are conducive to the enhancement of China's comprehensive national power, and the completion of China's economic, cultural and political construction. Only in this way can we achieve the goal of modernization and win the global competition.

Meanwhile, increasing the soft power of scientific and technological culture is the requirement of safeguarding national security, especially the national cultural security. In today's world, political multi-polarization and economic globalization further develop; science and technology change rapidly; ideas and culture exchanges become increasingly frequent. Cultural security becomes increasingly important in the national security system and exerts profound, subtle, long-term and fundamental impacts on national security. In order to maintain national cultural security, it is necessary for us to realize cultural self-improvement and build scientific and technological culture. Firstly, advanced soft power of scientific and technological culture can help us to improve scientific theories, create good social environments, improve scientific norms, and carry forward scientific spirit and thinking, so as to promote the combination of science, technology and economy, and realize the sustainable development of science, technology and culture. Secondly, improving the soft power of scientific and technological culture is the objective requirement of resisting cultural hegemony and safeguarding national cultural security. We need to prevent hegemonic countries from occupying Chinese cultural market and then control the Chinese nation through their advantages in scientific and technological culture. In order to effectively resist cultural hegemony and safeguard national cultural security, we must strive to realize cultural self-reliance, promote the continuous development of national scientific, technological and cultural soft power, and build a great socialist culture in China.

\subsection{Increasing the soft power of scientific and technological culture is the inevitable choice of China to realize the great rejuvenation, and to create a brand-new cultural image in front of the world.}

The strength of a country requires not only material strength such as economy, science and technology powers, but also cultural and spiritual strength. Cultural prosperity is the foundation of national rejuvenation and prosperity. The great rejuvenation of the Chinese nation is bound to be a process of greatly improvement in soft power of Chinese culture.

To build a culturally advanced country, China needs a new international image created by scientific and technological culture. Nowadays, China has become the second largest economy in the world. Economic development and cultural development cannot be separated. It is necessary to strengthen our cultural soft power and build a culturally advanced country; it is necessary to establish a new image of China in front of the world. The development of culture can show the mainstream ideology of a country. The development of science and technology can reflect the development level and current situation of science and technology. To build a culturally advanced country, we need to show our country's development strength on the international stage with the soft power of scientific 
and technological culture as representative. China is now following the road of socialism with Chinese characteristics. The constant development of scientific and technological culture shows Chinese characteristics, and can create a new image for our country in international ideological and cultural exchanges.

Improving the soft power of scientific and technological culture is conducive to the promotion of China's international influence. Culturally advanced country has strong national cohesion at home and big influence in the world. In the process of building a great socialist culture, besides constructing core value systems, developing national cohesion and promoting cultural development, we also need to focus on strengthening the influence of Chinese culture in the world. Relying on development in science and technology, we need to build advanced soft power of scientific and technological culture to fit China's international status. Therefore, the "going out" strategy should be vigorously implemented to improve the level of scientific, technological and cultural exchanges, to create new communication methods and forms, and to carry out international cooperation on science, technology and culture from various channels and at different levels. We also need to widely participate in the dialogue of world civilization, and promote Chinese culture in front of the world. Only in this way can we truly realize cultural self-improvement and lead our nation to a higher step.

In short, China's modernization can be seen as a process in which science and technology absorb traditional culture and constantly develop forward. China cannot build a great socialist culture without the development of science and technology, Science and technology constitutes the primary productive force; scientific and technological culture is the strong support of soft power in science, technology and culture, and an important element in the great socialist culture. The internal condition of socialist cultural construction is to improve citizens' comprehensive qualities; the external driving force is the continuous enhancement of the soft power of scientific and technological culture, which will ultimately promote the rapid development of economy. To follow the road of building a great socialist culture in China, we must increase the soft power of scientific and technological culture, since it has strategic significance for the construction of a culturally advanced country with Chinese characteristics.

\section{References}

[1] J.P. Xi, Report at the Nineteenth National Congress of the CPC, [EB/OL]. http://cpc.people.com.cn/n1/2017/1028/c64094-29613660.html

[2] E. Cassirer, An Essay on Man, Shanghai Translation Publishing House, Shanghai, 1985.

[3] K. Marx, F. Engels, Collected Works of Karl Marx and Friedrich Engels, People's Publishing House, Beijing, 2009.

[4] H.Z. Yang, Culture of Science and Technology and the Construction of a Harmonious Society in Contemporary China, China Social Sciences Press, Beijing, 2008.

[5] N.S. Huang, S.D. Gong, X.D. Chen, Research on Socialist Culture with Chinese Characteristics, Shandong People's Publishing House, Jinan, 1999.

[6] H.Z. Yang, Z.G. Pei, Scientific and technological culture: the inevitable choice of China's modernization, J. Journal of Wuhan University of Technology (Social Science Edition). 3 (2007) 300-301. 